\title{
Lifeworks
}

\section{From scalpel to sculpture}

“On Dr. Tait McKenzie's statue I have laid flowers of remembrance at the request of mothers and fathers who can never hope to see their lad in bronze. The last I laid was at the bidding of a mother, eighty years of age, an exile in South Africa. I had with me an American millionaire who had spent perhaps a thousand pounds while touring towards Edinburgh for the special purpose of keeping me company. As I laid the sprig of white heather at the feet of the bonnie Scottish laddie in bronze I bared my head. The millionaire stood, hat in hand, and when I ventured to look at him his eyes were streaming. So were mine."1

In I923 Canadian physician Robert Tait McKenzie was commissioned to create a war memorial in Edinburgh, as a tribute from Scottish-Americans to Scottish soldiers who died in World War I. McKenzie was a surgeon in WWI and also internationally known before the war for his sculptures of athletes in bronze. War memorials at the time were often the only form of "gravesite" that parents had for their dead sons, as bodies did not return home, and often battlefield graves could not be found. McKenzie's memorials (besides Edinburgh, he did one for Cambridge, England and one for Almonte, Ont.) always depicted just one soldier, young and idealistic, full of life, the son that parents could remember and a place where they could weep. - Cathy YoungerLewis, $C M A J$

\section{REFERENCE}

I. Scrymgeour N. The story of "The call." The Scots Magazine I932 July, as quoted in: McGill J. The joy of effort: a biography of $R$. Tait McKenzie. Bewdley (ON): Clay Publishing; 1980.

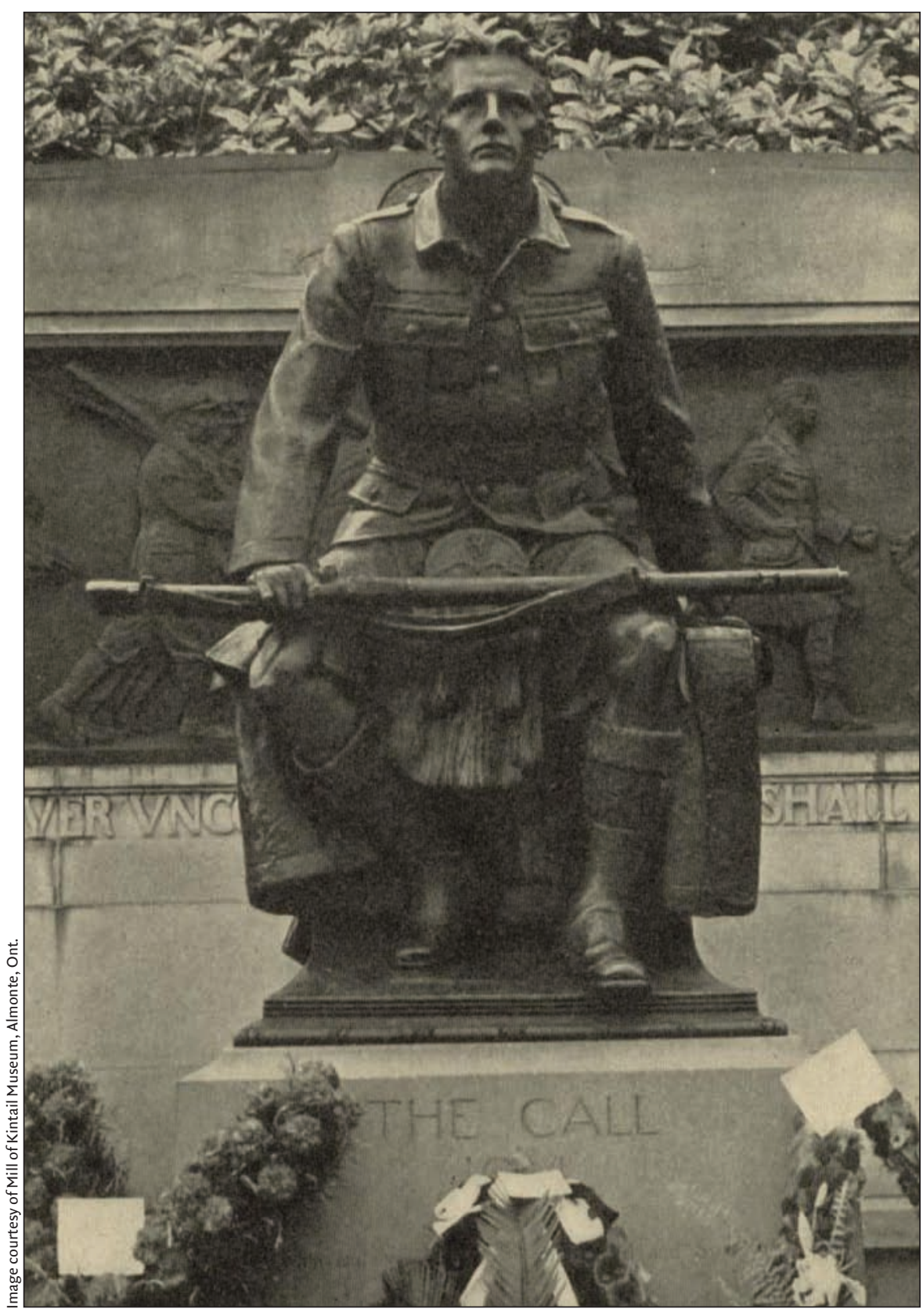

R. Tait McKenzie, The Call (1923-7). Bronze. Main figure $8 \mathrm{ft}$. high. Recruiting frieze on wall behind $25 \mathrm{ft}$. long. Scottish-American War Memorial, Princes St. Gardens, Edinburgh, Scotland. Plaster original of figure and frieze can be viewed at the Mill of Kintail Museum, Almonte, Ont. 